\title{
Frontline
}

\section{Journalism practice and critical reflexivity: A death in custody interview}

\section{ABSTRACT}

Critical reflexivity is a relatively recent strand in journalism studies. It has its advocates, but there are few models. This article offers one possible model, of one moment of practice: an interview with the mother-in-law of an Australian Indigenous woman who died an avoidable death in prison. The critically reflexive approach taken in this research accommodates the individual, social, objective and subjective elements in a practice, and uses the tools provided by Pierre Bourdieu's theory of practice and Donald Schön's work on reflective practice and the reflective practitioner. Together, these approaches provide different but complementary conceptual, analytical, practice-based and narrative tools for making journalism practice, and journalists in the practice, an object of study. Critical reflexivity, by adding an inside perspective, is a valid method by which to add to the range of journalism studies that examine journalism from the outside. Such research allows for an inter-weaving of context, self, others, relationships, theory, history, facts, values and experiences, expanding and enriching our understanding of journalism practice and its place in society.

Keywords: critical reflexivity, deaths in custody, Donald Schön, investigative journalism, Pierre Bourdieu, theory of practice, reflective practice.

\section{BONITA MASON}

Curtin University, Perth

7 HIS ARTICLE explores and seeks to explain an instance of journalism practice through one possible model for applying critical reflexivity to practice-led journalism research. The journalism practice 
concerned is that which produced an investigative feature about a 30-yearold Australian Indigenous woman, Janet Beetson, who died an avoidable death in a Sydney prison during the mid-1990s (Mason, 1997). The particular approaches to critical reflexivity employed in this research are those provided by Pierre Bourdieu's theory of practice and Donald Schön's work on reflective practice and the reflective practitioner. Together, these approaches provide different but complementary conceptual, analytical and practicebased tools for making journalism practice, and journalists in the practice, an object of study.

The critically reflexive model offered here is applied to previously published work, rather than work produced as part of the research, and therefore differs from the creative production-exegesis model of critically reflexive work (for an example, see Lindgren, 2011).

In this article, I set out relevant features of these approaches and identify the tools each approach offers to practice-led journalism research. I also take a specific moment in the practice that produced the story-my interview with Janet Beetson's mother-in-law, Dawn Delaney - as one example through which to explore how these approaches help me to understand and explain this moment of practice.

Dawn Delaney was the family protector, activist and spokesperson, and the central interviewee for the story. Her participation was critical to the story being told in a way that honoured Janet Beetson and sought to make accountable the systems that let her die (Mason, 2012, p. 167). Because Janet Beetson's family was still dealing with the legal and emotional consequences of her death, I knew I had to approach them in a way that was least likely to add to their trauma or cause further harm, and most likely to convince them to agree to participate. I wanted to research and write the story in a way that treated the family as if they were part of the audience for the article, and that brought 'heart', if not narrative justice (Shapiro, 2004), to those affected. In retrospect, I understand that I wanted to be both a 'caring agent' (McCabe \& Holmes, 2009, p. 1519) and strategic.

At the time, I knew this in a more-or-less acknowledged way, but my approach to the story, including the interview with Dawn Delaney, seemed almost instinctive (or unconscious). Applying the tools offered by the particular model of critical reflexivity outlined in this paper allows me to theorise, place in context and better understand this moment of practice. By becoming more conscious of some aspects of that practice in retrospect, 


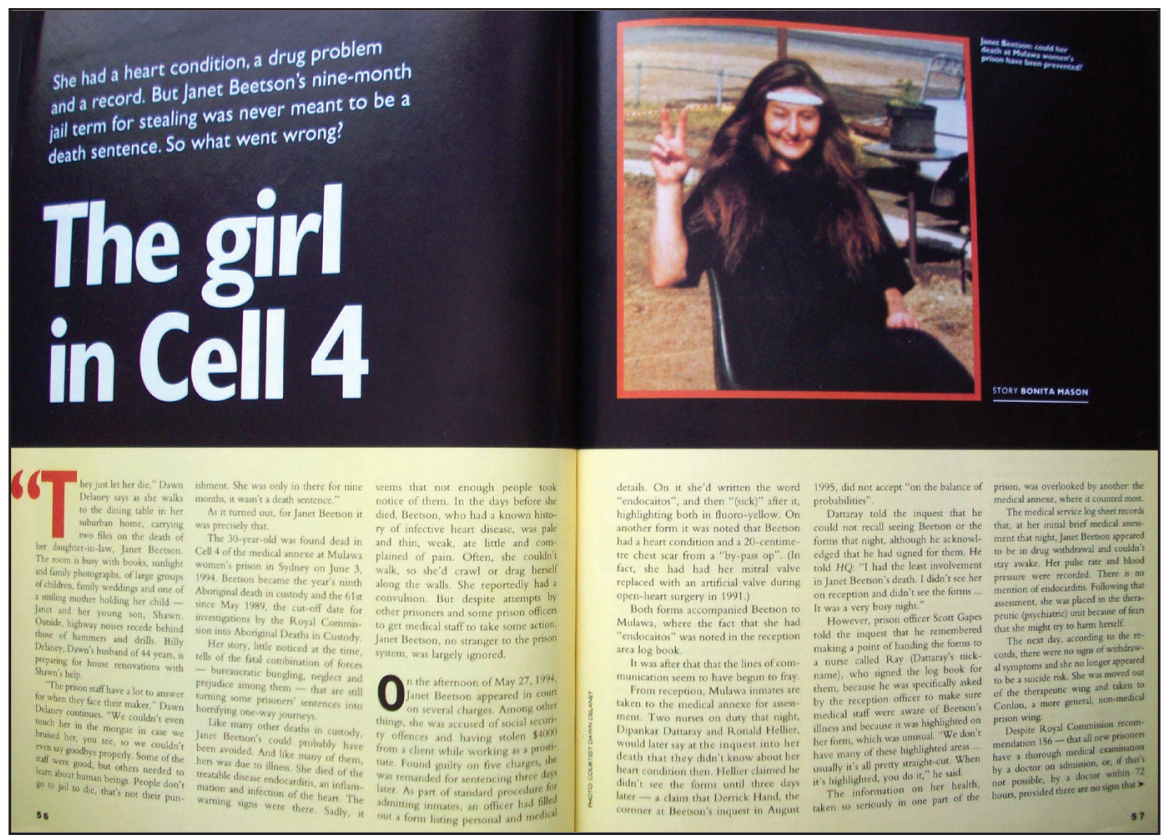

Figure 1: 'The girl in Cell 4' article opening page of $H Q$, March/April 1997.

I seek to make my journalism practice more conscious in the future.

This example of critically reflexive research is offered as just one way of approaching journalism research that makes our own journalism practice, and ourselves in the practice, an object for study. There may be elements in this work that apply to other, unique practice situations (Schön, 1971), but I do not claim that this one example of journalism practice, or of research into this practice, can be generalised. However, acknowledging those who have argued for this approach before me (such as Bacon 2006a, 2006b, 2012; Bromley 2006; McIntyre 2006; Niblock 2007), I advocate critical reflexivity as a suitable approach for researching at least some instances of the social practice of investigative journalism.

\section{Background}

Janet Beetson died in June 1994, in the Mulawa women's prison in Sydney's western suburbs (Mason, 1997). With timely and appropriate treatment for a heart condition, there is every chance she would have lived (Hand, 1995b, p. 3). I began working on the story of Janet Beetson's death in 1995 after 
assisting investigative journalist and academic Wendy Bacon, at the Australian Centre for Independent Journalism, with research into the media coverage of the recommendations of the Royal Commission into Aboriginal Deaths in Custody were being implemented by Australian national, state and territory governments (Bacon \& Mason, 1995).

I was also a student doing an investigative journalism subject as part of an MA degree at the University of Technology, Sydney (UTS) at the time. After finishing the UTS subject, I kept working on the story, when documents such as an extract of the Coroner's findings (Hand, 1995b) and the inquest transcript (Hand, 1995a) became available. The story aimed to both humanise Janet Beetson and call a system to account. It was published in the March/ April 1997 edition of the now defunct $H Q$ magazine.

The story seemed to meet some of its aims. Although there is no direct evidence that its publication led to any procedure or policy changes in the prison system (McCallum, et al, 2012), it did show that, in Janet Beetson's and similar cases, the media was neglecting to interrogate what was happening inside our institutions and to investigate the gap between what governments were saying and what they were doing. While the media was routinely reporting that Australian governments were implementing the Royal Commission's recommendations designed to reduce deaths in custody, prison deaths were at record levels (Bacon \& Mason, 1995; Mason, 2012).

Some years later, I chose this story as academic research material because it was sourced, researched and written from a marginal, freelance position in the journalism field, and because it was the product of unorthodox practices, particularly in the relationship between Dawn Delaney as a source, and myself as a journalist. This relationship, and the time required for trust to develop, was given precedence over deadlines and other more orthodox journalistic considerations.

Even though she was not happy with every detail in the published version of the story, Dawn accepted and celebrated the story's publication because, overall, she felt the story represented her daughter-in-law's case in a way that did her justice. The story also gave voice to Dawn's own outrage and sorrow about what had happened to Janet and about Aboriginal deaths in custody in general.

The story represented not only Dawn Delaney's perspective on these personal and social concerns, but also those of a group of prisoners who were in Mulawa at the time of Janet Beetson's death (Mason, 2012, p. 173-4). 


\section{INVESTIGATIVE JOURNALISM TRENDS}

Prisoners wrote to the $H Q$ editor that they felt the story had provided an 'honest account of the unnecessary death of Janet Beetson' (Names Withheld, 1997). The letter was published in the next edition. Like Dawn Delaney, the prisoners were concerned with both the individual and the social. They wrote about the lack of media coverage, and how that silence reflected their status as women prisoners and made them more vulnerable. The story had represented the experience of Janet Beetson's family and of the prisoners in a way they recognised as truthful. It had also recognised their value as members of a broader community, and acknowledged their suffering (Berger, 1998; Shapiro, 2004).

To the extent that the story appeared to meet some of its objectives, I wanted to know how I, an inexperienced journalist on the margins of the journalism field, had achieved this. I was concerned to understand what I had done according to 'instinct', or unconsciously, and to make the understandings and methods of this particular journalism practice more conscious.

The tools provided by the specific approaches to critical reflexivity outlined below offer a means for exploring these questions.

\section{Critical reflexivity and journalism research}

Critical reflexivity is a relatively new strand of inquiry in journalism studies (for Australian examples, see Bacon, 2006b; Skilbeck, 2009; Lindgren, 2011; Mason, 2012; Waller, 2012). It is a form of analysis requiring a socially, historically and discursively situated researcher (Kemmis \& McTaggart, 2000, p. 577) to engage in the study of the self - 'as both inquirer and respondent, as teacher and learner'-within the research (Lincoln \& Guba, 2000, p. 183).

Critically reflexive research also reaches beyond the self. It seeks to expose and understand the forces - such as the conventions, routines and structures in a practice, and practitioner and/or researcher understandings and ways of working - that limit decision-making and curtail the development of practices that provide more human autonomy and agency (McCabe \& Holmes, 2009, p. 1520). It is, therefore, both personal and political.

Journalism is a social practice (MacIntyre, cited in Aucoin, 2005, p. 5) conducted by individual journalists. While we seek through journalism practice to discover, describe and make sense of the real those things outside ourselves and external to the practice of journalism (the objective), we bring our subjectivities (those things internal to ourselves and our field of practice) to the task. Any study of journalism practice, therefore, needs to take account 
of its individual, social, objective and subjective elements, and of the interrelationships between them.

The approach which defines critical reflexivity as 'practice as reflexive, to be studied dialectically' (Kemmis \& McTaggart, 2000, p. 578) allows for such an analysis. The researcher and/or practitioner seeks critical self-awareness through understanding where the self is located within power relations and structures - in Bourdieu's term, within a 'field' (Bourdieu, 2005) - and in the connections within and between them. She needs to understand and acknowledge her own interests, and how what she brings both enables and limits the research and practice.

Through personal accounting, researchers must become more aware of how their own positions and interests are imposed at all stages of the research process - from the questions they ask to those they ignore, from who they study to who they ignore, and from problem formation to analysis representation and writing - in order to produce less distorted accounts of the social world (Hertz, 1997, p. viii).

The production of 'less distorted accounts of the social world' (Hertz, 1997, p. viii) is the aim of critical reflexivity. It is also the aim of much investigative journalism, a practice concerned with engaging and changing the social world (Ettema \& Glasser, 1998). It was important to Pierre Bourdieu, who sought a 'self-critical objective social science' (Swartz, 1997, p. 277). Bourdieu recognised the inseparability of work on the self-as both a subject and object for study - and empirical work on the social world (Bourdieu, 2007, pp. 59, 69). The individual (journalist) and social worlds (journalism field and broader society) are connected through practice. Critical reflexivity is therefore relational research into a practice that is itself a set of relations. It invites the practitioner and researcher to interrogate the self as one of the forces shaping journalism practice, in relation to other practice-shaping forces, such as the routines and structures of the mainstream newsroom or the introduction of new technologies. Such self-interrogation can be an act of journalistic transparency and accountability.

Critical reflexivity offers the journalism field a method for conducting practice-led research, and a perspective on journalism practice from the inside (McIntyre, 2006; Bacon, 1999, 2006a; Niblock, 2007). It also offers a means to reflect on how changes in our practice might make us better able to report 


\section{INVESTIGATIVE JOURNALISM TRENDS}

more comprehensively (Mody, 2011), expressing a more expansive range of human values in our journalism (Ettema \& Glasser, 1998) and telling a broader range of stories from more points of view. In this research, critical reflexivity also enables me to produce an account of an instance of journalism practice that is as free of unconscious distortion as I am able to, at this moment in my academic practice.

The 'practice as reflexive, studied dialectically' model of critical reflexivity provides the overall approach for this research, a kind of umbrella for the more specific approaches that provide the research tools and techniques. The connections between investigative journalists, journalism practice and the broader society are accommodated by the specific approaches to critical reflexivity employed-Pierre Bourdieu's and Donald Schön's.

\section{Pierre Bourdieu, critical reflexivity and journalism}

The tools provided by Bourdieu's theory of practice, which conceives of action as taking place within a field - and in the relationships between capital (power) relations, habitus and field (outlined below) - are primarily conceptual. His approach to reflexivity offers a broad and comprehensive framework for an analysis incorporating the subjective, objective, collective and individual elements in practice and therefore for understanding social structures, power relations, practices, norms and values, actors and agency, all in relation to each other.

Bourdieu's work was concerned with the inter-generational reproduction of patterns and structures of domination (Calhoun \& Wacquant, 2002), 'without powerful resistance and without the conscious recognition of their members' (Swartz, 1997, p. 6). Finding out how existing power relations were presented and accepted as the natural 'order of things' (Bourdieu, in Bourdieu and Wacquant, 1992, p. 168) was central to his work. These motivations gave rise to Bourdieu's concept of 'epistemic reflexivity' (Calhoun \& Wacquant, 2002), where taken-for-granted structures, patterns and relations of domination and subordination - and ways of representing, understanding and legitimating them-are recognised and acknowledged. This acknowledgement was also to apply to the power relations between the researcher and researched, and to their respective positions and perspectives (Kenway \& McLeod, 2004, p. 527). Therefore, a task for reflexive sociology is to conduct what Bourdieu termed 'socioanalysis': to make conscious the 'social unconscious', which contains 
unacknowledged and embedded interests that are held and exercised by groups and individuals within an 'unegalitarian social order' (Swartz, 1997, p. 10). Bourdieu's reflexive sociology seeks to politicise that which is depoliticised and unacknowledged, or, in Bourdieu's term, 'misrecognised' (Calhoun \& Wacquant, 2002; Swartz, 1997, p. 89-90).

A recent Western Australian study (Kerr \& Cox, 2013) into the media coverage of a Nyoongar tent embassy, set up on an culturally significant island in the Swan River on the edge of the Perth CBD, found that, although much of the WA mainstream media began their coverage with Nyoongars land and justice concerns, the media coverage quickly shifted to reflect state concerns about criminality, threat and nuisance. In this case, the Nyoongar people peaceably camping on the island at the time, asserting their sovereignty rights, were defined as threats to the community, a symbolic act that excluded them from membership of the broader community. Kerr and Cox noted that the media reporting repeatedly relied on 'underlying assumptions, prejudices and systems of meaning that have been naturalised' (Fairclough, cited in 2013, p. 16). That is, they had become misrecognised as taken-for-granted in an 'order of things' (Bourdieu, in Bourdieu and Wacquant, 1992, p. 168) that is perpetuated, or lent 'symbolic force' (Bourdieu \& Passeron, quoted in Swartz, 1997 p. 89), by media reporting. Kerr and Cox's analysis of this recent example of journalism practice demonstrates that misrecognition continues to characterise much Indigenous affairs reporting.

Bourdieu provides conceptual tools for analysing how journalism and journalists may reinforce or challenge the natural order of things; whose interests journalism serves; and for theorising the position and voicelessness of people and groups dominated and disadvantaged by the order of things. His tools also enable an individual practitioner to examine and identify both her position in the journalism field and what she brings to the practice, in this case to the relationship with Dawn Delaney. The research in this article does not make a full field analysis; it applies Bourdieu's specific concepts as they relate to the case study.

\section{Theory of practice}

Bourdieu's theory of practice is a 'probing reflection' on the relationship between the society and the individual, which stems from the insight that 'social reality exists both inside and outside of individuals, both in our minds and in things' (Swartz, 1997, p. 96)..Practice is produced in the 


\section{INVESTIGATIVE JOURNALISM TRENDS}

connections between power, structure and culture (1997, p. 9), and in the interactions between capital, habitus and field, and their respective and inter-related histories (1997, p. 141).

\section{Capital/s}

Capital is power relations and, because capital is unequally distributed, it determines social position (Swartz, 1997, p. 74). Capital can be economic, cultural, social or symbolic, and is expressed in a field through habitus (see below).

Economic capital dominates other forms of capital and includes money, assets and the control of labour to produce wealth (Swartz, 1997, p. 74; Bourdieu, quoted in Swartz, 1997, pp. 79-80; Nash, 2007). In the journalism field, economic capital is evident in circulation figures, audience rating and advertising revenues (Benson \& Neveu, 2005, p. 4).

Cultural capital is education, technical skills, general knowledge, communication skills and artistic sensibilities (Swartz, 1997, p. 74; Benson \& Neveu, 2005, p. 4). Cultural capital in the journalism field takes the form of 'professional excellence': investigative, in-depth reporting, informed and influential commentary and journalism awards (Benson \& Neveu, 2005, p. 4).

Social capital is 'more or less institutionalised relationships of mutual acquaintances and recognition' (Bourdieu, quoted in Benson \& Neveu, 2005, p. 21, f/n 16). It is who you know and, perhaps, how you fit in.

Symbolic capital is recognition and legitimacy (Benson \& Neveu, 2005, pp. 4, 21) - the capacity to make meanings, to define how a set of circumstances or an issue will be presented and understood, and decide whose point of view is legitimated (Bourdieu, 2005, pp. 37-8). Symbolic capital may be employed to produce misrecognition (Bourdieu, cited in Swartz, 1997, p. 93).

These dynamics provide part of the context for the 'critical exploration' (Bacon, 1999, p. 85) in the case study. Where relevant, I identify my own capital 'stocks' and explore how they were expressed, through habitus, in my journalism practice.

\section{Habitus}

Habitus, as a set of dispositions, is the manifestation of internalised history (Wacquant, in Bourdieu \& Wacquant, 1992, p. 16). As an expression of cultural capital, it is about how people see themselves and each other, and how they act in the world or practise in a field. Like capital, habitus is relational. 'To speak of habitus is to assert that the individual, and even the personal, 
the subjective, is social, collective' (Bourdieu, quoted in Benson and Neveu, 2005, p. 3).

Habitus is embodied in individuals through primary socialisation, which begins with the family and is the most important, and secondary socialisation, ongoing education and experience (Benson \& Neveu, 2005, p. 3). Socialisation results in internalised perceptions, aspirations, assumptions and judgements that influence behaviour and set the boundaries of what is possible (Neveu, 2007, p. 339; Benson \& Neveu, 2005, p. 3; Swartz, 1997, p. 103). Habitus therefore generates and structures action, but is not 'fate' (Bourdieu, in Bourdieu \& Wacquant, 1992, p. 133). Practitioners acting in a field according to their dispositions shape practice and is shaped by it.

While most people encounter experiences that reinforce their habitus, because they tend to move in the specific social worlds that shaped their dispositions (Bourdieu, in Bourdieu \& Wacquant, 1992, p. 133), habitus can be transformed by 'self work', where individuals come to a conscious understanding of their dispositions (Bourdieu \& Wacquant, 1992, p. 133, f/n 86). Such attempts to consciously understand embodied dispositions are important in critically reflexive research because the researcher represents a factor that may limit the research findings (Hartley, 2002, p. 84).

Habitus enables me to analyse, and draw out the correspondence between, inherited and acquired dispositions and how, and from where, I practised to produce the story. Using Bourdieu's conceptual framework, I can identify my position, as a marginal practitioner, not socialised into a newsroom, as occupying the 'sub-field of small-scale production' (Hesmondhalgh, 2006, p. 214). The features of this position include low levels of economic capital and high levels of autonomy relative to those occupying a more mainstream or orthodox position (Ibid, pp. 214-5), which matched my experience at the time.

As a freelance journalist with an alternative part-time income, I was unconstrained by the routines and structures of mainstream news production, including deadlines, story competition, editorial preferences and privileging official sources (Ericson, et al, 1989; Reich, 2010). No one told me what story to write, how to write it and when to file it by. I was also free of the 'industrial discipline' of 'objectivity as ideology' (Schudson, 2001, p. 162), and the 'truth-as-violence tradition' of the mainstream newsroom, where the 'journalist-insider ... must keep at arm's length both their public and their sources' (Hartley, 1999, p. 233). 
As habitus explains my field position and features of my journalism practice, it also structures an analysis of the relationship between myself and Janet Beetson's family members as sources for the story.

\section{Field}

The field is the 'space' where habitus expresses itself and negotiates its position; where different forms of capital/power are accumulated, competed for, converted and exercised; and where struggles take place over who or what will define what is legitimate in the field - the orthodoxy or mainstream, or the heterodoxy or challengers (Hesmondhalgh, 2006, p. 215; Swartz, 1997, p. 124-5).

A field is a network of connections, which operate within it and extend beyond its porous boundaries. While the socialised individual connects to the field via their habitus, the field connects to society through its relationships to other fields (Benson \& Neveu, 2005). The journalism field contains markets and institutions, such as media organisations, regulators, journalism education and training institutions and programmes, and journalists' associations and unions. It contains less formal groups, such as a freelance journalists' group, a foreign correspondents' group, and Women in Media, all of which are also networks that might include members of other fields. Within and between these field structures, 'symbolic producers ... compete for symbolic capital' (Swartz, 1997, p. 117).

The dialectical relationship between orthodox and heterodox positions, actors and strategies is one of many practice-shaping dynamics in the networks of connections that operate both within and between fields. For example, the competition for symbolic capital is central to position and action. Journalists act to define and make explicit how something should be understood, and compete to have their definitions recognised as legitimate representations of the social world (Bourdieu, in Benson \& Neveu, 2005, p. 37). As journalists seek to expose the effects of power relations in other fields, such as political or corporate fields, they may contribute to transforming power relations in those fields, or between those fields and others. They will only achieve such transformation if their definition of what has taken place, and its significance, is accepted as legitimate in those other fields.

A similar practice-structuring dynamic is in play within a field. A journalist occupying a position in the sub-field of small-scale production (Hesmondhalgh, 2006, p. 214) will enjoy more autonomy but less recognition. Journalists in the 
'sub-field of large-scale production' (newsroom and elite journalists), with high levels of economic capital and low levels of symbolic capital (Hesmondhalgh 2006, p. 214), have less autonomy but more recognition. Through Bourdieu's concept of field, I can explain the autonomy I had when writing the story. I can also contextualise my attempt to have the story recognised as legitimate through publication in $H Q$ magazine and by entering the story into journalism awards, as I sought to have the story's publication contribute to transforming power relations in other fields.

Although Bourdieu's tools provide a framework for conceputualising my connections to, and position within, the journalism field and to broader social structure, and their possible influence on my practice, Donald Schön's work on the reflective practitioner provides more specific and practical tools for critically examining the practice.

\section{Donald Schön and reflective practice}

Philosopher and social scientist Donald Schön $(1971,1991,1987)$ focused on the study of practice by individuals working within organisations. He was concerned with critical, self-reflective practice and provided the concepts and practical methods of reflection-in-action and reflection-on-action for self-awareness, continuous learning, and individual and institutional transformation.

\section{Reflection-in-action}

Reflection-in-action is thinking about and adapting what we are doing as we do it. It involves 'looking to our experiences, connecting with our feelings, ... attending to our theories in use ... [and] building new understandings to inform our actions' (Smith, 2001). When the researcher-practitioner reflects in action they do not separate means and ends, or thinking and doing, but consider and enact them together, experimenting on the spot, as the 'researcher in a practice context ... constructs a new theory of the unique case' (Schön, 1991, p. 68). Reflection is the bridge between theory and practice. Despite time and other pressures, reflection-in-action is possible in journalism because journalism is a process of constant editorial decision-making, where 'thinking on our feet' (Schön, 1991, p. 54) is 'the enactment of a sophisticated process of judgement borne out of experience' (Niblock, 2007, p. 25).

To reflect-in-action, Schön suggests a series of questions practitioners 
may ask themselves about their practice: the features of the practice; how a problem is framed and what criteria, values or norms underlie judgement and action; whether patterns of feeling and/or behaviour emerge through the practice; and the role adopted by the practitioner within their institution (Schön, 1991, pp. 50, 62). These reflection-prompting questions form a set of possible tasks for the reflective practitioner. The resulting understandings - which may have been implicit in the practitioner's action-are brought to the surface, analysed, perhaps re-framed and/or restructured and embodied in further action (Schön, 1991, p. 50).

\section{Reflection-on-action}

The reflective questions above may also be applied to the retrospective reflection-on-action - thinking back after the event or encounter to what we did, or how something went, adding what we learned to our repertoire of norms and practices. As we take time to 'explore why we acted as we did' (Smith, 2001), we can develop new strategies for future practice (Niblock, 2007, p. 25).

Reflection-on-action is therefore reflection-in-action plus time and distance. The contention that reflection-on-action requires the practitioner to use their repertoire of past experiences, images, ideas and metaphors to frame an unexpected situation differently (Smith, 2001) — either in 'a conversation with themselves' (Sheridan Burns, 2002, p. 53) or with colleagues - is 'important to creative practice' (Smith, 2001). This process is at work in journalism. In a study of journalists' practice, and of the fit between actual practice and recognised theories about journalism, Niblock and Machin found that 'while journalists have a remit to look forward and anticipate the next news cycle, a good deal of their previous experience was brought to bear upon subsequent judgements' (cited in Niblock, 2007, p. 25).

In this article, I use Schön's concept of reflection-on-action to look back on how I 'thought on my feet' - reflected-in-action and adapted practice-during the interview with Dawn Delaney. As I reflect, I pay particular attention to my relationship with Janet Beetson's family as story sources. Reflection-in-action and reflection-on-action are analytical, practice-based tools.

\section{Case study}

This case study is one small example of how the tools and understandings offered through Bourdieu's concepts of capital, habitus and field and Schön's 
reflective techniques may be applied to a critical examination of one small moment - the interview with Janet Beetson's mother-in-law, Dawn Delaney - in the practice that produced the Janet Beetson story. It explores how I more-or-less consciously moderated myself and my journalism practice in relationship with Dawn - how I reflected-in-action; and what elements of that practice, and my practice-shaping habitus, have since become more conscious as a result of reading and applying Bourdieu's conceptual tools - a contextualised reflection-on-action.

I approached Dawn Delaney for an interview because I believed that the family's participation was critical to telling the story in a way that highlighted the human consequences of the story. I wanted to elicit both sympathy and outrage in response to what had happened to Janet, and hoped to contribute to a more humane and competent prison system. These aspirations accorded with my dispositions in favour of social and other forms of justice and to think and act politically. These dispositions plus another, to tread carefully, shaped my indirect and gradual approach to the family. As well as seeking to avoid adding to their trauma, I wanted to show respect and, perhaps, offer some comfort and redress through telling Janet's story.

Dawn Delaney agreed to meet. I drove the $36 \mathrm{~km}$, mostly along freeways, from Sydney's inner west to Sydney's outer western suburbs, where Dawn Delaney, her husband and Janet's teenage son lived. I was nervous. This was a very serious and important interview; my first of its type as a journalism student. I didn't know if my interviewing skills were good enough, if I would handle it properly, if I would upset and somehow harm the family, if I would be able to write the story I wanted to, if I was actually capable of writing the story I wanted to.

I realise now that I had two apparently contradictory dispositions. One for under-confidence and another for attempting what seemed to be beyond me. These dispositions - both limitation and capacity - formed through primary socialisation in my childhood home, a place touched by the experiences of migration, mental illness, occasional violence, social isolation, and an interest in and a concern for justice and politics. Our family, which could hardly care for itself, fostered an Aboriginal toddler who grew up with us. Through Bourdieu's conceptual framework, I can now see myself as both the socialised individual and as an individual expression of the social (Bourdieu, cited in Swartz, 1997, p. 96). This, and what follows, is the story of the interview with Dawn. It is self work (Bourdieu, 2007). 
I arrived. Dawn met me, holding two files on her daughter-in-law's death in her arms. We went into the dining room,

a room busy with books, sunlight, and family photographs, of large groups of children, family weddings and one of a smiling mother holding her child - Janet and her young son, Shawn. Outside, highway noises recede behind those of hammers and drills. Billy Delaney, Dawn's husband of 44 years, is preparing for house renovations with Shawn's help (Mason, 1997, p. 56).

We sat at the table, and started work. In the days and weeks that followed, I began to detect a kind of prejudice in my attitude to Dawn, which I did not fully articulate and understand at the time. I know now that I had made an unconscious assumption: that people come in recognisable packages. I was already aware of what had happened, and was happening, in her family and it seemed I had made assumptions about them based on their experiences and circumstances and, perhaps, on where they lived. Without expecting or wanting to, I had assumed Dawn Delaney would act more like a victim, would seem less organised and in control of what she was doing and how she was doing it. Despite my best intentions, I had misrecognised her according an internalised version of the order of things, where I was the one with the university education, middle-class life and possible access to the media-my cultural and social capital stocks, which I assumed she did not possess.

Dawn was well-organised, across all aspects the 'case' - its personal, human, institutional and policy dimensions - and often took the initiative, telling me what she wanted me to know. She was articulate, provided good quotes which opened and closed the story, and knew what she had verified and what I needed to check to ensure that the story was accurate. Even though I did not recognise them during our interview, I did check myself and responded to what was in front of me, rather than acting from my assumptions.

Very soon into the interview Dawn was crying:

I feel they have a lot to answer for when they face their maker. We couldn't even touch her in case we bruised her, you see, so we couldn't even ... [crying] ... say goodbye properly. Some of the staff were good, but others needed to learn about human beings, that they are human beings. They don't go to jail to die, that's not their punishment. She was only in there for nine months this time - it wasn't a death sentence, but they gave her a death sentence (Delaney, 1995). 
Dawn cried more throughout the three-hours, especially when talking about Janet and how she'd been treated. She was willing to feel distress and to continue with the interview, but became stronger when talking about the authorities, the recommendations of the Royal Commission into Aboriginal Deaths in Custody, how other women prisoners had tried to help Janet, and what she thought should be done. She set the pace and I repeatedly, or continuously, read and responded to the nuances and currents in the interview, to its pulse, and to how she was. I leant in when it felt right; at other times I sat back and gave her more space. We stopped for a cup of tea. I gave her my complete attention. I cried with her. I was on her side; there was no place for the arms-length of orthodox reporting.

I recognise now that I was always going to take a careful, watchful approach to the interview. Growing up in a house that could explode at any time, with a parent who may commit suicide, sharpens the senses. Dispositions for vigilance, to read and anticipate a situation, a mood, a phrase, and to bring calm when necessary - acquired in the family home and honed as a ministerial adviser in my twenties - are, again, both limitation and capacity. How to check if something's going to be okay?

I sought layers of permissions (Shapiro, 1994). Before asking a question to follow up on how Janet was during the days before she died, I asked if it was all right to ask about that, then or perhaps later. I told Dawn I would not include in the story or publish any of what she has told me without checking with her first. I agreed to show her the drafts as the story developed. She could cease her participation in the story at any time, and I would not seek to publish if she did not want me to.

These actions represent an instance of reflection-in-action informed by my status as an inexperienced and freelance journalist. The relative autonomy of my freelance position enabled me to allow the time for the relationship of mutual trust and collaboration to build with Janet Beetson's mother-in-law, to make unorthodox agreements, and express through my journalism practice values generally unrecognised but present in much investigative journalism, such as solidarity (Ettema \& Glasser, 1998). Again, these understandingsand an awareness of the limitations of mainstream newsrooms and much mainstream journalism - have come about through reflection-on-action, in conversations with myself, with others and from the journalism studies literature (for example, Tuchman, 1978; Hall, Critcher, Jefferson, Clarke \& Roberts, 1978; Schlesinger, 1987). ${ }^{1}$ 
Even though I have now recognised my unconscious assumption about Dawn, part of my being careful then - my reading and responding - came from an awareness of the possible cultural complexities in her family. Dawn Delaney was a non-Aboriginal woman married to an Aboriginal man with an Indigenous grandchild, for whom she had become responsible. These were complexities I recognised.

As I was researching and writing the story in New South Wales, my Aboriginal sister in Western Australia had been having a hard time. In a state with the highest Indigenous imprisonment rate in Australia relative to nonIndigenous prisoners - 21 times higher in WA compared to 15 times higher nationally (Australian Bureau of Statistics, 2013) — my sister became one of those young Aboriginal people stopped and questioned by Perth police because their shoes are too new, too expensive-looking. She and her shoes ran counter to the 'habitual conception' of Aboriginal people in Perth (Kerr \& Cox, 2013, p. 16) at the time-misrecognition. I was at a Sydney bus stop shortly after the story was published and asked myself why, beyond a social and political commitment, I'm so concerned about Aboriginal deaths in custody and what happens inside prisons. The answer: 'So I can keep [my sister] safe.' Socialisation, feeding disposition, shaping practice.

\section{Conclusion}

Together, Pierre Bourdieu's theory of practice and Donald Schön's work on reflective practice provide conceptual, analytical and practice-based tools for critically examining the practitioner and a practice, and connecting them to the field and broader society. They account for the individual, social, subjective and objective elements in a practice, and the relationships between them. If a researcher-practitioner is to ask the question of how to be an accountable, ethical journalist (and researcher) who produces useful and meaningful work, a more complete critical reflexivity might be part of the answer.

By making the story of the circumstances of Janet Beetson's death public, and placing that story in a social, policy, governmental and institutional context, I sought to define the deaths in custody issue within the journalism field, and have that definition accepted as legitimate, while influencing actors in the governmental, justice and other fields in the broader society. Bourdieu's concepts enable me to theorise these field and power dynamics, and to understand my attempt at definition and legitimation as both an expression, through habitus, of the symbolic capital available to me at the time, and an attempt to 
counter misrecognition surrounding the implementation of the Royal Commission's recommendations. Bourdieu provides both a means of understanding these dynamics and a language for describing them.

Habitus is the central concept for the case study. It enables me to make my subjective self an object of study through an analysis of what I brought to the interview with Dawn Delaney. In the practice of journalism, practitioner dispositions represent a set of skills and capacities that are both limiting and enabling. One of the possible consequences of under-confidence, for example, is over-research, not a bad thing for investigative journalism — although it can be hard to know when the story's finished and should be published.

The same applies for researcher dispositions. While the researcher represents a limiting factor in the research, researcher capital/s and habitus are also qualities and capacities. For example, my disposition for introspection makes it more likely that I will undertake critically reflexive research.

An awareness of the benefits of occupying a marginal freelance position in the journalism field has arisen through this critically reflexive research. Rather than suspecting myself of failure to make the mainstream grade, I now appreciate the possibilities (including for countering misrecognition) of occupying a relatively autonomous position, and my habitus continues to transform in favour of greater understanding and agency. Although, it must also be acknowledged that my position as a journalist in a university brings a great deal of social and cultural capital, not least through institutional affiliation.

Critical reflexivity, by adding an inside perspective to journalism studies, is a valid method by which to add to the range of journalism studies that examine journalism from the outside. This article has attempted to offer one possible model for critically reflexive research - through the conceptual, analytical and practice-based tools offered by Bourdieu and Schön. Such research allows for an inter-weaving of context, self, relationships, others, theory, history, facts, values and experiences, expanding and enriching our understanding of journalism practice and its place in society.

\section{Note}

1. There are many more and more recent studies have identified the limitations in mainstream journalism, but I cite these examples because they are early and comprehensive newsroom studies that remain influential and valuable in journalism studies. 


\section{INVESTIGATIVE JOURNALISM TRENDS}

\section{References}

Aucoin, J. L. (2005). The evolution of American investigative journalism. Columbia, MO: University of Missouri Press.

Australian Bureau of Statistics. (2013). 4517.0 - Prisoners in Australia, 2013. Retrieved from www.abs.gov.au/ausstats/abs@.nsf/Lookup/4517.0main+featur es322013

Bacon, W. (1999). What is a journalist in a university? Media International Australia, incorporating Culture and Policy, 90, 79-90.

Bacon, W. (2005). A case study in ethical failure: Twenty years of media coverage of Aboriginal deaths in custody. Pacific Journalism Review, 11(2), 17-41.

Bacon, W. (2006a). Journalism as research? Australian Journalism Review, 28(2), 147-57.

Bacon, W. (2006b). Journalism as research?: Thinking about journalism research in an Australian university context. Retrieved from https://artsweb.aut.ac.nz/pmc/ docs/papers/Journalism_as_research_Bacon.pdf

Bacon, W. (2012). An innovative direction in academic journalism. Pacific Journalism Review, 18(2), 153-165.

Bacon, W. \& Mason, B. (1995, Autumn). Aboriginal deaths in custody: A dead issue? Reportage, 5. Sydney: Australian Centre for Independent Journalism, University of Technology, Sydney.

Benson, R. \& Neveu, E. (2005). Bourdieu and the journalistic field. Cambridge, UK: Polity Press.

Berger, J. (1998). In Jansen, R. (writer and director). John Berger: A kind of grace, Masterpiece, SBS (copyright Humanisticsche Omroep Stichting 1996).

Bourdieu, P. \& Wacquant, L. J. D. (1992). An invitation to reflexive sociology. Cambridge, UK: Polity Press.

Bourdieu, P. (2005). The political field, the social science field, and the journalistic field. In R. Benson \& E. Neveu (Eds.), Bourdieu and the journalistic field (pp. 29-47). Cambridge, UK: Polity Press.

Bourdieu, P. (2007). Sketch for a self-analysis. Cambridge, UK: Polity.

Bromley, M. (2006). How good is journalism research? Australian Journalism Review, 28(1), 211-217.

Calhoun, C. \& Wacquant, L. (2002). In memoriam: Pierre Bourdieu (1930-2002). Retrieved December 23, 2009, from www.theglobalsite.ac.uk/times/202calhoun.htm

Cole, P. \& Harcup, T. (2010). Newspaper journalism. London, UK: Sage Publications.

Curran, J. (2002). Media and power. London, UK: Routledge.

Delaney, D. (1995). Mason, B. (Interviewer). Transcript of interview.

Ericson, R. V., Baranek, P. M. \& Chan, J. B. (1989). Negotiating control: A study of news sources. Milton Keynes, UK: Open University Press.

Ettema, J. S. \& Glasser, T. L. (1998). Custodians of conscience: Investigative journalism and public virtue. New York, NY: Columbia University Press.

Hand, D. (1995a, August 14). Inquest into the Death of Janet Lorraine Beetson. Glebe: New South Wales State Coroner's Court, W608 326/95 JI-D2. 
Hand, D. (1995b, August 18), Inquest into the Death of Janet Lorraine Beetson: Extract. Glebe: New South Wales State Coroner's Court, W644 330/95 VL-C1.

Hall, S., Critcher, C., Jefferson, T., Clarke, J. \& Roberts, B. (1978) Policing the crisis: Mugging, the state, and law and order. London: MacMillan.

Hartley, J. (1999). Why is it scholarship when someone wants to kill you? Truth as violence. Continuum: Journal of Media and Cultural Studies, 13(2), 227-236.

Hartley, J. (with additional material by M. Montgomery, E. Rennie and M. Brennan) (2002). Communication, cultural and media studies: The key concepts (Third Edition). London, UK: Routledge.

Hertz, R. (Ed.) (1997). Reflexivity and voice. Thousand Oaks, CA: Sage.

Hesmondhalgh, D. (2006). Bourdieu, the media and cultural production, Media, Culture \& Society, 28(2), 211-231.

Kemmis, S. \& McTaggart, R. (2000). Participatory action research. In N. K. Denzin and Y. S. Lincoln (Eds.), Handbook of Qualitative Research (Second edition) (pp. 567-605). Thousand Oaks, CA: Sage Publications Inc.

Kenway, J. \& McLeod, J. (2004). Bourdieu's reflexive sociology and 'spaces of points of view': whose reflexivity, which perspective? British Journal of Sociology of Education, 25(4), 525-544.

Kerr, T. \& Cox, S. (2013). Setting up the Nyoongar tent embassy. In Ctrl-Z. Retrieved from www.ctrl-z.net.au/wp-content/uploads/2013/08/Setting-Up-theTent-Embassy-Kerr-Cox.pdf

Lincoln, Y. S. \& Guba, E. G. (2000). Paradigmatic controversies, contradictions, and emerging confluences. In Y. S. Lincoln \& N. K. Denzin (Eds.), Handbook of Qualitiative Research (pp. 163-188). Thousand Oaks, CA: Sage Publications, Inc.

Lindgren, M. (2011). Journalism as research: Developing radio documentary theory from practice. Unpublished doctoral thesis, Murdoch University. Retrieved from http://researchrepository.murdoch.edu.au/5858/

Mason, B. (1997, March/April). The girl in Cell 4, in F. Souter (Ed.), HQ. Sydney: Australian Consolidated Press Magazines.

Mason, B. (2012). 'The girl in Cell 4': Securing social inclusion through a journalistsource collaboration. Media International Australia, 142, 167-176.

McCabe, J. L. \& Holmes D. (2009). Reflexivity, critical qualitative research and emancipation: A Foucauldian perspective. Journal of Advanced Nursing, 65(7), 1518-1526.

McCallum, K. (Ed.) (2012). The media and indigenous policy: How new media reporting and mediatised practice impact on indigenous policy, A preliminary report. Retrieved from www.canberra.edu.au/media-centre/attachments/pdf_folder/ MIP-Report_Combined_Final.pdf

McIntyre, P. (2006). Creative practice as research: 'Testing out' the systems model of creativity through practitioner based enquiry. Speculation and innovation: applying practice led research in the creative industries. Retrieved from http://artsresearch. brighton.ac.uk/links/practice-led/McintyreP.pdf

Mody, B. (2011). Educating journalism students to do comprehensive reporting. Asia Pacific Media Educator, 21, 43-50. 


\section{INVESTIGATIVE JOURNALISM TRENDS}

Names Withheld (1997, May/June). From behind bars [letter to the editor]. In F. Souter (Ed), HQ. Sydney: ACP.

Neveu, E. (2007). Pierre Bourdieu: Sociologist of media, or sociologist for media scholars? Journalism Studies, 8(2), 35-347.

Nash, C. (2007, 8 March). A sociology of the professions-Pierre Bourdieu, UTS lecture transcript.

Niblock, S. (2007). From 'knowing how' to 'being able': Negotiating the meanings of reflective practice and reflexive research in journalism studies. Journalism Practice, 1(1), 20-32.

Schlesinger, P. [1978] 1987. Putting 'reality'together: BBC News. London: Methuen.

Schön, D. A. (1971). Beyond the stable state: Public and private learning in a changing society, London, UK: Maurice Temple Smith Ltd.

Schön, D. A. ([1983] 1991). The reflective practitioner: How professionals think in action. England: Ashgate Publishing Limited.

Schön, D. A. (1987). Educating the reflective practitioner: Toward a new design for teaching and learning in the professions. San Francisco, CA: Jossey Bass.

Schudson, M. (2001). The objectivity norm in American journalism. Journalism, 2(2), 149-170.

Shapiro, B. (2004). McLachlan, D. (Interviewer). Trauma in the newsroom. Cultures of journalism, ABC Radio National. Retrieved on September 5, 2008, from www.abc.net.au/rn/learning/lifelong/stories/s 1174646.htm Shapiro, B. (2007, 4 December). In Adams, P. (Interviewer). Late night live. ABC Radio National.

Sheridan Burns, L. (2002). Understanding journalism. London, UK: Sage.

Skilbeck, R. (2009). Arts journalism and exiled writers: A case study of fugal, reflexive practice, Pacific Journalism Review, 15(2), 132-151.

Smith, M. (2001). donald schon (schön): Learning, reflection and change. Infed. Retrieved November 16, 2009, from www.infed.org/thinkers/et-schon.htm

Swartz, D. (1997). Culture and power-the sociology of Pierre Bourdieu. Chicago, IL: University of Chicago Press.

Tuchman, G. (1978). Making news: A study in the construction of reality. New York, NY: Free Press-Macmillan.

Waller, L. (2012). Reciprocity and indigenous knowledge in research. In K. McCallum (Ed.), The media and indigenous policy: How new media reporting and mediatised practice impact on indigenous policy, A preliminary report. (pp. 89-96) Retrieved from www.canberra.edu.au/media-centre/attachments/pdf_folder/MIPReport_Combined_Final.pdf

\section{Acknowledgements}

I want to acknowledge and thank Dr Ann McGuire for her excellent advice on an early draft; the PJR peer reviewers for their encouragement and generous suggestions; and Professor Wendy Bacon who introduced me to Bourdieu and Schön and, years later, continues to encourage and support my research and practice. 
Dr Bonita Mason is a journalism lecturer at Curtin University, who teaches first-year journalism, feature writing and specialist Indigenous reporting. She has published in books and magazines, and is an award-winning freelance journalist. She has also worked as a policy adviser and speechwriter for government and as a media and policy adviser and writer for Aboriginal organisations in the Kimberley and elsewhere.

bonita.mason@curtin.edu.au

\section{Update your media skills in 2014}

The Australian Centre for Independent Journalism at the University of Technology, Sydney offers a range of short courses that provide a fast way to update and improve the writing and media skills of people working within the media, government and corporate environments.

Our lecturers are industry

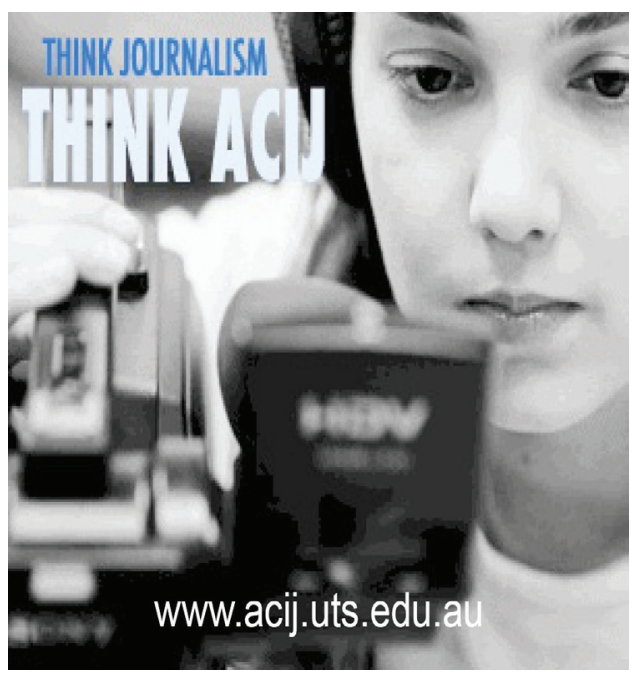
professionals and experienced educators.

Check out our short courses today at www.acij.uts.edu.au 